\title{
LINGUISTICS
}

UDC 882.035

DOI: $10.17223 / 24109266 / 6 / 1$

\section{PRESERVATION OF THE ORIGINAL'S STYLE AS A BASIC PRINCIPLE OF THE TRANSLATION (as an example of the drama by A.P. Chekhov "Three Sisters")}

\author{
E.A. Adam \\ National Research Tomsk State University (Tomsk, Russian Federation). \\ E-mail: Janeadva@rambler.ru
}

\begin{abstract}
The subject of research is one German translation by P. Urban of Chekhov's drama "Three sisters" with examples of national-cultural realities and popular language. Main attention is devoted to the clarification of the translator's ability for the creation of the author's style in its variety.
\end{abstract}

Keywords: drama; A.P. Chekhov; translation; P. Urban; Germany.

\section{Introduction}

2014 - a memorable year for connoisseurs A.P. Chekhov - 110 years ago the writer passed away. Already in the middle of the last century his legacy, including drama, received international recognition and status of the "timeless classics". A definite role was played in it by translators. The direct dependence of perception of productions of foreign-language plays from the quality of their translations Austrian researcher Klaus Bednarz (Klaus Bednarz) [1] pointed out yet in 1969. Since the 1980s most translators, following a new fashion and recommendations by directors deliberately deviate from the original, modifying the author's text. In this article as an example of the drama "Three Sisters" is given to the analysis of the translation of contemporary German Slavonic philologist and publisher Peter Urban (Peter Urban) [2], which remains true to the original. The main task of this translator is to convey to the readers of "the author's intention" [3:29].

\section{Research}

P. Urban born in July 16, 1941 in Berlin, began to research the works of Chekhov from the end of 1960s. Preliminary analyzed available at that time the German translations of the works by this Russian writer, he comes to the conclusion that they did not consider the real Chekhov, the artist for whom the language is not only a means of communication, but also material for puns at different language levels. Urban writes that the translators did not 
notice for a long time "amazing simplicity of Chekhov's language", "think out something different. But no one has annuled the old rule that the translator must always adhere to the style of the original" [4: 36].

For more than 40 years Urban is devoting himself to translations, publication and promotion of creativity of this Russian writer. From 1972 till 1974 were published 8 volumes Chekhov's plays in his translation. In 1976 as editor of the Zurich publishing house "Diogenes Verlag" he forms from existing individual translations 10 volumes of prose, and in 1979 published five-volume edition of the letters of the writer in his own translation. For this work in 1980 Urban was awarded an international prize to promote scientific and artistic translation of the name of Helmut M. Braem. Thanks to this translator in Germany were published complete works of all works, letters, diaries and notebooks of Chekhov in German, "what was not deigned yet to any other Russian writer" [5: 225]. In the last 20 years Urban is working on another major project - new complete works of this Russian writer. His purpose is - to introduce to the German reader "with the works of Chekhov as much as an approximate" [4:37].

The designations of specific national-cultural realities, which have no analogues in the translation's language, are usually offer for translators essential lexical difficulties. Most often in such cases is used a transliteration method. One of the founders of the national school of translation theory A.V. Fedorov is convinced: "There is no word that could not be translated into another language, at least descriptively, that is as extended combination of words of the native language. But transliteration is exactly necessary when it is important to observe the lexical brevity of notation corresponding to its familiarity in the original language, and at the same time to emphasize the specificity of the known things or concepts, if there is no exact conformity in the translation's language " [6: 140]. In the drama "Three Sisters" in the most cases Urban preserves realities, specific for Russia. He uses in Russian sounding words such as "nurse", "samovar", "vodka", "kwas", "verst", "troiyka", "blini”" and "Zemstvo".

Special attention in the play deserve such specific names as "wild garlic" (wild onions) and "chehartma" (Caucasian dish). Urban not only keeps it in the transliteration, but also gives an explanation in the "Notes" that accompany his translation. In this case by Chekhov is important not so much the meaning of words proper (marked realities), but the similarity of their sound shell, and so the transliteration is here inevitable. The "Notes" of Urban indicative of the special translation's conscientiousness, manifested in the careful attention to national realities and aspiration for interpretation of the essence of the comic, which is being built here on completely different semantics of seemingly similar words.

The names of the characters are used in accordance with the generally accepted in the Russian language model (surname, name, patronymic) without any cuts, and also in transliteration. A characteristic feature of translations by Urban is the use the diacritics marks of Slavic languages, their ex- 
planations are also given in the "Notes"; for example: $\check{c}$ - "tsch", wie "Čechov"; š - immer stimmloses, scharfes "sch", wie in "Asche"; šč - immer

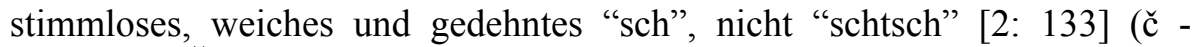
"tsch", as "Čechov"; š - always toneless, sharp "sch" as in the German word "Asche"; šč always toneless, soft and extent of the sound "sch", not "schtsch"). The translator bases the chosen method of modern philological practice: "The transcription of Russian names follows so-called scientific, international, typical for Slav philology transcription, which uses the Cyrillic alphabet for specific sounds, for their precise differences, diacritics marks of those Slavic languages that are written in Latin - such as Czech, Slovak, Slovenian, Croatian and, in part, Serbian" [Ibid].

The transmission of various styles of speech of characters is another one of those complicated tasks that solves translator. In the drama "Three Sisters" are used different variants of popular speech, analysis of its transmission in a foreign language brings the ability of translator to recreate the author's style in its diversity, to consistent and adequate speech characteristics of the characters, as well as to transmission of specific for popular speech close connection with the domestic environment, individual for the people and the era, and cultural realities. In his first translation of this drama (1974) Urban reproduced in transliteration and such specific Russian treatment as "batyushka" and "matushka". However, in the revised edition of 1999, he, like other translators, replaces them with German words with a similar meaning. The speech of nurse Anfisa, for which is characteristic a folk-country kind of popular language, as a special stylistic stream permeates the text of the drama, the voices of other characters echo with it. Her first entrance falls on act $\mathrm{I}$, and the first sentence contains as a stylistic signal the word "batyushka" [7: 125], addressed to Ferapont. Urban offers an equivalent expression - "mein Guter" [2: 15] (my good). The same treatment, too from the mouth of Anfisa, but in relation to Vershinin, appears twice in act II [7: 148-149]. The translator has consistently adhered to his first version "mein Guter". For the translation of the treatment by Anfisa "matushka" [Ibid] with respect to Masha Urban uses the equivalent pet shape - "Liebes" [2: 44] (sweet). However, this version does not convey the right sense of the complex, which is associated with this treatment in the Russian language. The words "batyushka" and "matushka" have folk nuance and are pet shape. These are traditional treatments used not only in Russian everyday practice, but also in Russian culture in general. For an adequate transmission of such cultural realities, it may be useful to apply the transliteration and make commenting explanation.

In the same act I Anfisa, applying to the youngest of the sisters, asks her: “Аринушка, ты же будь ласковая, вежливенькая...” [7: 126] (Arinushka, be affectionate, politely...). Specific in this phrase is the use of popular speech form of the name, the form of the adjective with diminutive suf- 
fix, colloquial particle "as" and incorrect case forms of the adjective. The translator, seeking to accurately convey the affectionate tone of Anfisa's voice, uses an adverb with intensive value - "schön". This adverb gives to the adjective in German exactly diminutive value, which in Russian sounds like "very" and in conjunction with the adjective "polite" - as "politely". The proposed version conveys quite accurately the lexical and the syntactic meaning of this phrase Anfisa: "Arinuška, sei schön freundlich, schön höflich..." [2: 16] (Arinushka, be very gentle, very politely...).

In act II Anfisa speaks of Vershinin with the phrase "Экой какой" [7: 149] (What a man). This phrase has very compact sense, although no direct lexical meanings. Urban kept the grumbling tone of the phrase, which is in the original, but could not pass its "well ordered", internal symmetry: "Das ist mir einer" [2: 45].

In act I Anfisa, representing Ferapont with a cake, explains: "Из земской управы, от Протопопова, Михаила Иваныча...” [7: 125] (From Zemstvo-council, from Protopopov, Mikhail Ivanovich...). The translation corresponds to the original, it keeps to the style of the speech: "Von der Zemstvoverwaltung, von Protopopov, Michail Ivanyč..." [2: 15].

In act II Anfisa, applying to Vershinin, says: “...простите, батюшка, забыла имя, отчество...” [7: 148] (...I'm sorry, my dear fellow, I forgot your name, patronymic...). The expression "name - patronymic" is a stable formula both in a conversational style, and in popular speech, and reflects the Russian tradition of interpersonal communication. In Germany the word "Vatersname" (patronymic) means the name of the father and in communication is not used, and the word "Name" can indicate both name or surname and name and surname simultaneously. This national-cultural differences are due to the deviation in the analyzed translation: "ich habe Ihren Namen vergessen..." [2: 44] (I forgot your name...).

Specific for Chekhov's drama was that the popular language is not only for the speech characteristics of the character, but also to complete the whole artistic-semantic ensemble of the play. In the play are shown a few variants of popular speech, including - soldiers-philistine, with a clerical bureaucratic nuance, which belongs to watchman Ferapont. This character is although the lowest, but a certain rank in the state-social structure. The first cue of Ferapont when he asks again: "Чего?" [7: 125] (Why?), performs in it a specific speech characteristics. The translation of this cue by Urban - "Wie was?" [2: 15] (As what?), consisting of a non-existent in the German literary combination of two interrogative words, describes very accurately Ferapont.

In act III in the speech of this character is shown his usual style of a soldier. During the fire, he repeatedly executing instructions repeats: "Слушаю" [7: 158] (Listen). The transmission of this phrase into German is not too much difficulty because it has already the stable literary equivalent, fixed in a Russian-German dictionary, - "Zu Befehl", - which borrows for his 
translation Urban [2: 56]. In act II Ferapont answers Andrei: “..да не пускали все. Барин, говорят, занят. Ну, что ж. Занят так занят, спешить мне некуда" [7: 140] (...still not allowed. The master, is said, is busy. Well. Busy so busy, I have nowhere to hurry) [Ibid]. In Russian this construction has a comic origin, namely the element of absurdity as a result of repetition, duplication; and the translation is simply repeated that looks like illogic: "...aber man hat mich nicht vorgelassen. Der Herr, sagt man mir, ist beschäftigt. Na gut. Ist er beschäftigt, dann ist er beschäftigt, ich habs nicht eilig" [2: 34] (...but I did not let in. The master, is said, is busy. Well, good. If he's busy, then he is busy, I am not in a hurry). The translator replaces a chopped, primitively constructed phrase of Ferapont about the master with one coherent, complex structure, not characteristic for the speech of this characters.

The next cue of Ferapont: "Не могу знать... Слышу-то плохо..." [7: 141] (I can not know... I hear something bad...) consists of two sentences, the first of which is characteristic for the "service class" and is stable in Russian idiom. Urban did not convey this speech characteristics, as in the first sentence disappeared military clearness, which is the basis of phraseological, in the second is smoothed popular speech: "Kann ich nicht sagen... Ich höre schwer..." [2: 34-35] (I can not say... I hear bad).

\section{Conclusion}

Thus, in this translation of the drama "Three Sisters" are as a whole kept speech styles, that is particularly important for the dramatic text, intended for delivery from the scene and called to form the stylistic diversity of living speech, and to mark out in it the voices of individual characters. Urban, in the words of critic K. Hielscher, considers the works of Chekhov first of all as linguistic works of art [8: 86].

\section{References}

1. Bednarz, K. (1969) Theatralische Aspekte der Dramenübersetzung. Dargestellt am Beispiel der deutschen Übertragungen und Bühnenbearbeitungen der Dramen Anton Čechovs. Wien: Verlag Notring. $300 \mathrm{~s}$.

2. Čechov, A. (1999) Drei Schwestern. Drama in vier Akten. Übersetzt und heraugegeben von Peter Urban. Zürich: Diogenes Verlag. $145 \mathrm{~s}$.

3. Urban, P. (1972) Čechov übersetzen. Theater heute. 5. pp. 29-33.

4. Goebel, J. (2010) I need peace. Deutschland. 2. pp. 36-37.

5. Kluge, R.-D. (1997) Chekhov in Badenweiler. Literary heritage. Moscow: Nauka. 100. Chekhov and world literature. (Bk. 1). pp. 218-226.

6. Fedorov, A.V. (1953) Introduction to the theory of translation. Moscow: Publishing House of Literature in Foreign Languages. 335 p.

7. Chekhov, A.P. (1986) Complete works and letters: In 30 v. Works: In 18 v. 13: Plays 18951904. Moscow: Nauka. 526 p.

8. Hielscher, K. (1984) Die Rezeption A.P. Čechovs im deutschen Sprachraum seit 1945. Girke W., Jachnow H. (hrsg.). Aspekte der Slavistik. Festschrift für Josef Schrenk. München. pp. 73-101. 